\title{
Electron microscopy study of magnetosomes in two cultured vibrioid magnetotactic bacteria
}

\author{
FIONA C. MELDRUMํ, STEPHEN MANN ${ }^{1}$, BRIGID R. HEYWOOD ${ }^{1}$, \\ RIGHARD B. FRANKEL ${ }^{2}$ AND DENNIS A. BAZYLINSKI ${ }^{3}$ \\ ${ }^{1}$ School of Chemistry, University of Bath, Claverton Down, Bath BA2 7AY, U.K. \\ ${ }^{2}$ Department of Physics, California Polytechnic State University, San Luis Obispo, California 93407, U.S.A. \\ ${ }^{3}$ Department of Chemistry and Chemical Engineering, Stevens Institute of Technology, Castle Point on the Hudson, Hoboken, \\ New Jersey 07030, U.S.A.
}

\begin{abstract}
SUMMARY
Magnetite $\left(\mathrm{Fe}_{3} \mathrm{O}_{4}\right)$ crystals produced by two strains of cultured vibrioid magnetotactic bacteria were studied by high-resolution transmission electron microscopy (HRTEM). Both magnetotactic strains were characterized by single chains of magnetite crystals aligned along the long axes of the cells. The strains, designated as MV-2 and MV-4, produced crystals that differed markedly in size and morphology. Crystals present in MV-4 cells were generally larger than those in MV-2 cells and displayed significantly smaller aspect ratios. Crystallographic analysis of the magnetosomes of MV-2 revealed an elongated hexagonal habit based on a prism of $\{110\}$ faces capped by $\{111\}$ faces. The axis of elongation was parallel to the $\langle 111\rangle$ direction. This morphology closely resembles the crystal shape of magnetosomes in a previously described vibrioid species MV-1. In contrast, magnetosomes of MV-4 possessed a cubooctahedral morphology which was modified by a small elongation along the $\langle 211\rangle$ direction. Although this morphology has not previously been observed in magnetotactic bacteria, it appears to be intermediate between the regular cubo-octahedral shape of magnetosomes in the cultured species Aquaspirillum magnetotacticum and the extensively elongated cubo-octahedral crystals of a previously studied uncultured ovoid-shaped magnetotactic bacterium. The results support the proposal that the crystal morphologies of bacterial magnetite are strain specific.
\end{abstract}

\section{INTRODUCTION}

Although the existence of magnetotactic bacteria has been recognized for over 15 years (Blakemore 1975; Blakemore et al. 1980), it is only recently that several new species and strains have been isolated in pure culture (Bazylinski et al. 1988; Matsunaga et al. 1991; Schleifer et al. 1991): these include bacteria with spirilloid and vibrioid morphologies. A coccoid-shaped bacterium has also been successfully maintained in enrichment (Moench 1988) and pure (Meldrum et al. 1993 ) cultures. The isolation of new magnetotactic bacterial strains is essential for the investigation of the cellular properties of these unusual organisms as well as the elucidation of the magnetic and structural aspects of iron biomineralization processes in bacteria. In this regard, at least three distinct types of crystal morphology have been observed in magnetotactic bacteria containing magnetite $\left(\mathrm{Fe}_{3} \mathrm{O}_{4}\right)$ particles (Mann \& Frankel 1989). These include isotropic cubo-octahedral particles (Mann et al. 1984a), elongated cubooctahedral crystals (Mann et al. $1987 a b$ ), and elongated hexagonal prisms (Matsuda et al. 1983; Mann et al. 1984b; Sparks et al. 1990). The latter have variations in the number and type of truncated faces but appear to be bacterial strain specific. Recently, we have shown that changes in the chemical conditions of the culture medium can result in minor modifications in the crystal morphology of magnetosomes in the cultured coccus, strain MC-l (Meldrum et al. 1993). In this paper, we use high-resolution transmission electron microscopy (HRTEM) to characterize the morphological and structural features of magnetite crystals produced by two newly cultured, previously undescribed, vibrioid magnetotactic bacterial strains. Our results show that although both strains are vibrioid in cellular morphology, the associated magnetosomes are different in shape and size, suggesting that the biomineralization of intracellular magnetite in these two organisms involves biochemical processes that are strain- and possibly species specific.

\section{MATERIALS AND METHODS}

Two magnetotactic bacterial strains were studied. The first, designated strain MV-2, is vibrioid-to-helicoid in morphology, and was isolated from water collected from the Pettaquamscutt Estuary, Rhode Island, U.S.A. Cells of this strain are Gram-negative and motile by means of a single polar flagellum. It appears identical to strain MV-1 (Bazylinski et al. 1988) based on phylogenetic analysis of their 

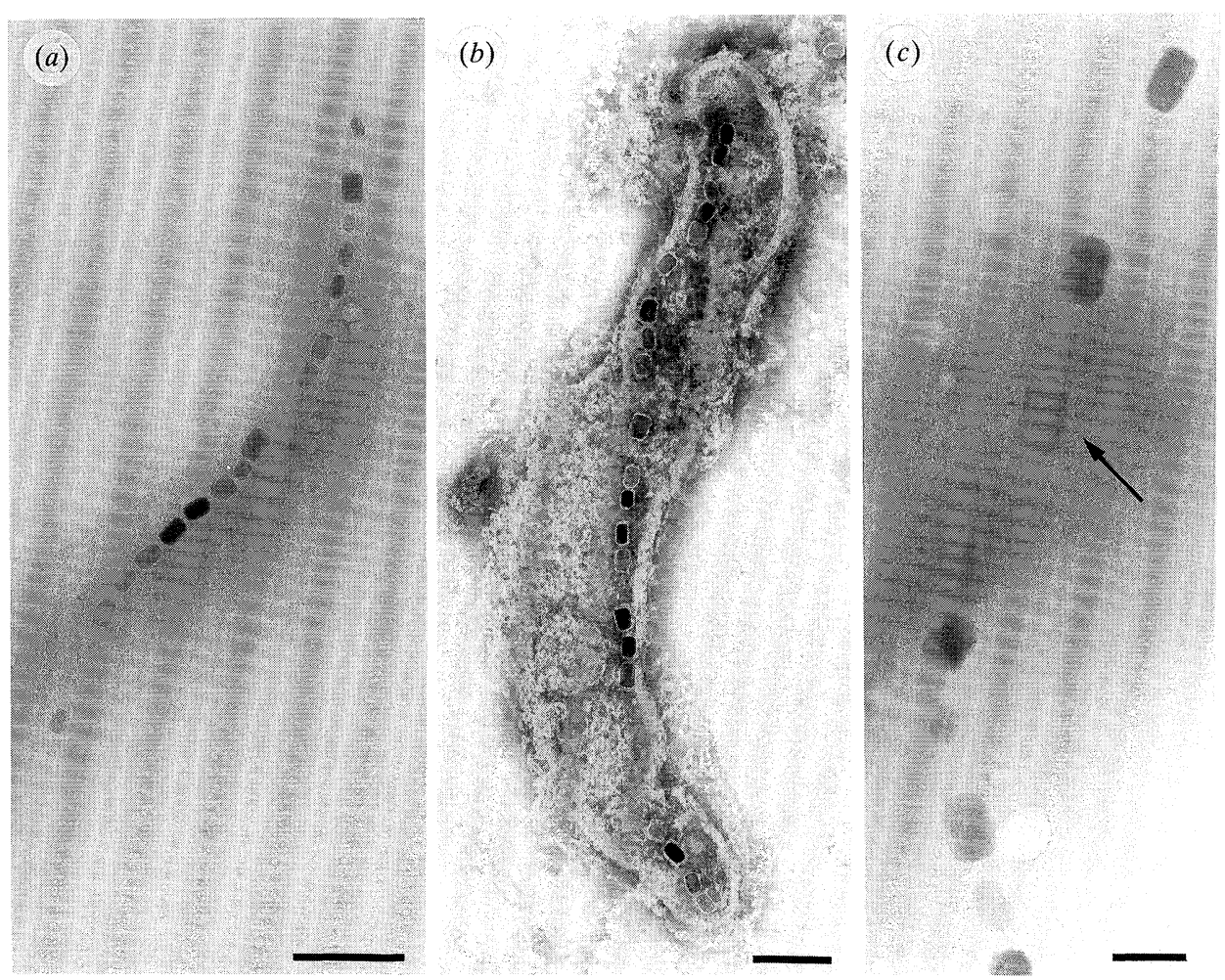

Figure 1. Transmission electron micrographs of $(a)$ unstained cell of magnetotactic strain MV-2 (scale bar = $200 \mathrm{~nm}$ ), and (b) negatively stained MV-2 bacterium (scale bar $=200 \mathrm{~nm}$ ). (c) Higher magnification of the magnetosome chain in a MV-2 cell showing twinned crystal (arrow). Scale bar $=50 \mathrm{~nm}$.

Table 1. Statistical data for magnetosomes produced by $M V-2$ cells

\begin{tabular}{|c|c|c|c|}
\hline & mean & $\begin{array}{l}\text { standard } \\
\text { deviation }\end{array}$ & range \\
\hline $\begin{array}{l}\text { number of crystals per } \\
\text { bacterium }\end{array}$ & 17 & 4 & $7-23$ \\
\hline length/nm & 48 & 5 & $30-59$ \\
\hline width/nm & 26 & 7 & $28-40$ \\
\hline aspect ratio & 1.8 & 0.3 & - \\
\hline
\end{tabular}

small subunit ribosomal RNA sequences (DeLong et al. 1993). It is probable, therefore, that strains MV-1 and MV2 are the same species. The second, designated strain MV-4, is also vibrioid-to-helicoid in morphology and was isolated from mud and water from School Street Marsh, Woods Hole, Massachusetts, U.S.A. Cells of strain MV-4 are Gramnegative and bipolarly flagellated.

Both strains were grown in semi-solid oxygen gradient media (D. A. Bazylinski, unpublished data) under different physiological conditions. Strain MV-2 was grown under chemoautolithotrophic conditions in an inorganic oxygensulphide double gradient medium. Cells of strain MV-4, which did not grow in the presence of sulphide, were also grown under these conditions in an inorganic medium with thiosulphate as the energy source and under chemoheterotrophic conditions with succinate as the carbon and presumed energy source. Both strains were grown until microaerophilic bands of cells formed in the culture tubes. Cells were removed from the cultures with sterile syringes.

Electron microscopic (Ем) studies of intact cells were done using a JEOL 2000FX transmission electron microscope (тем), fitted with a Link windowless elemental dispersive $\mathrm{X}$ ray (EDX) detector and operating at $200 \mathrm{kV}$. Statistical data on crystal sizes and frequency were obtained from a population of 100 cells of strain MV-2 and 85 cells of strain MV-4. Over 200 crystals were measured for each strain. Sample grids containing air-dried MV-4 cells were treated with $1 \%$ (by volume) sodium hypochlorite solution before recording high-resolution lattice images to remove extraneous Agar from the culture medium, the presence of which greatly reduced image resolution. On completion of the microscopic studies of strain MV-2, the sample grid was negatively stained with $4 \%$ methylamine tungstate solution.

High-resolution TEM (HRTEM) images were recorded at a magnification of $\times 500000$ by using an objective aperture of $80 \mu \mathrm{m}$. The lattice fringe spacings measured from micrographs were corrected according to a calibration done on the microscope by using a gold foil at a magnification of $\times 500000$ and a voltage of $200 \mathrm{kV}$. The fringe spacings were indexed by comparison with published data for magnetite: space group $\mathrm{Fd} 3 \mathrm{~m}$, with lattice parameter $a=0.8394 \mathrm{~nm}$.

\section{RESULTS}

\section{(a) Strain $M V-2$}

Individual bacteria were elongated in morphology and contained a single chain of intracellular anisometric magnetosomes which were aligned along the long axis of the cell (figure 1). The chains comprised rectangular magnetite crystals oriented with their principal axes parallel to the chain direction. Many cells consisted of incomplete chains in which there were regions devoid of crystals, resulting in gaps within the magnetosome chain. However, the structural alignment of crystals separated by these discontinuities remained consistent, suggesting that all the crystals were spatially constrained within a contiguous cellular 
Table 2. Statistical data for magnetosomes produced by $M V-4$ cells

\begin{tabular}{|c|c|c|c|}
\hline & mean & $\begin{array}{l}\text { standard } \\
\text { deviation }\end{array}$ & range \\
\hline $\begin{array}{l}\text { number of crystals per } \\
\text { bacterium }\end{array}$ & 17 & 5 & $8-31$ \\
\hline length/nm & 61 & 12 & $22-85$ \\
\hline width/nm & 52 & 11 & $18-80$ \\
\hline aspect ratio & 1.2 & 0.1 & - \\
\hline
\end{tabular}

matrix. Immature crystals were observed at different positions along the chain and not specifically at the ends of the assembly, as has been commonly observed in the cells of the coccoid bacterium strain MG-1 (Meldrum et al. 1993). Twinned crystals, in which the twin boundary comprised a central plane running
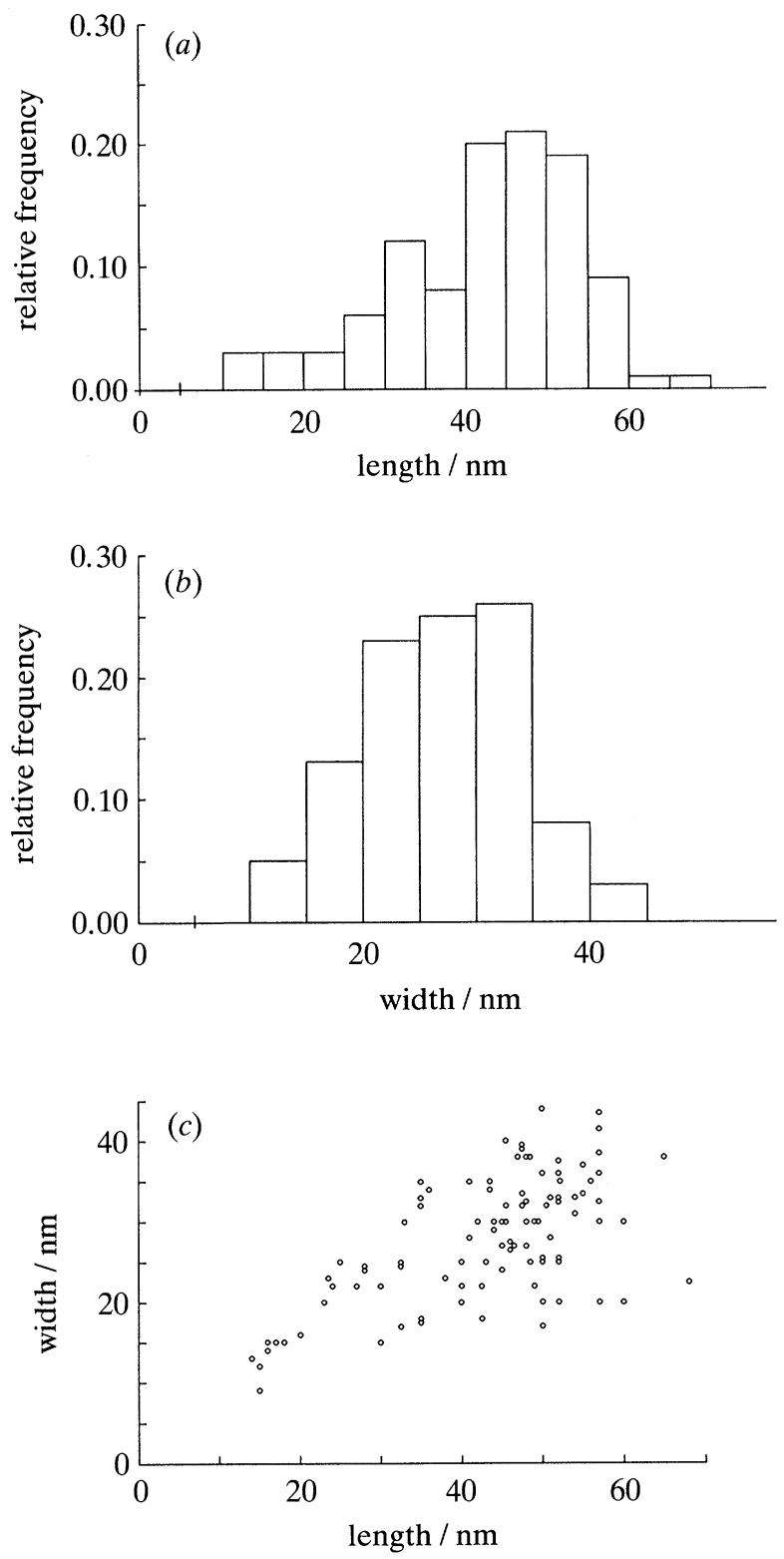

perpendicular to the crystal long axis, were occasionally observed (figure $1 c$ ).

There was a marked variation in crystal size between different bacteria and along individual chains (tables 1 and 2, figure 2). The graph of length against width (figure 2c) demonstrates that there is considerable variation in aspect ratio for crystals of given length, suggesting that the rates of crystallization of individual particles in sulphide-grown MV-2 cells may fluctuate significantly.

Lattice images of individual crystals showed combinations of $\{111\},\{220\},\{200\}$ and $\{311\}$ magnetite fringes. A high-resolution image of a typical magnetosome produced by MV-2 cells is shown in figure 3 . The lattice fringes are continuous throughout the particle suggesting that the magnetosome is a well-defined single crystal. Crystals imaged along the $\langle 110\rangle$ direction showed two sets of $\{111\}$ fringes and a set of $\{200\}$ fringes (figure $3 b$ ). The orientation of these
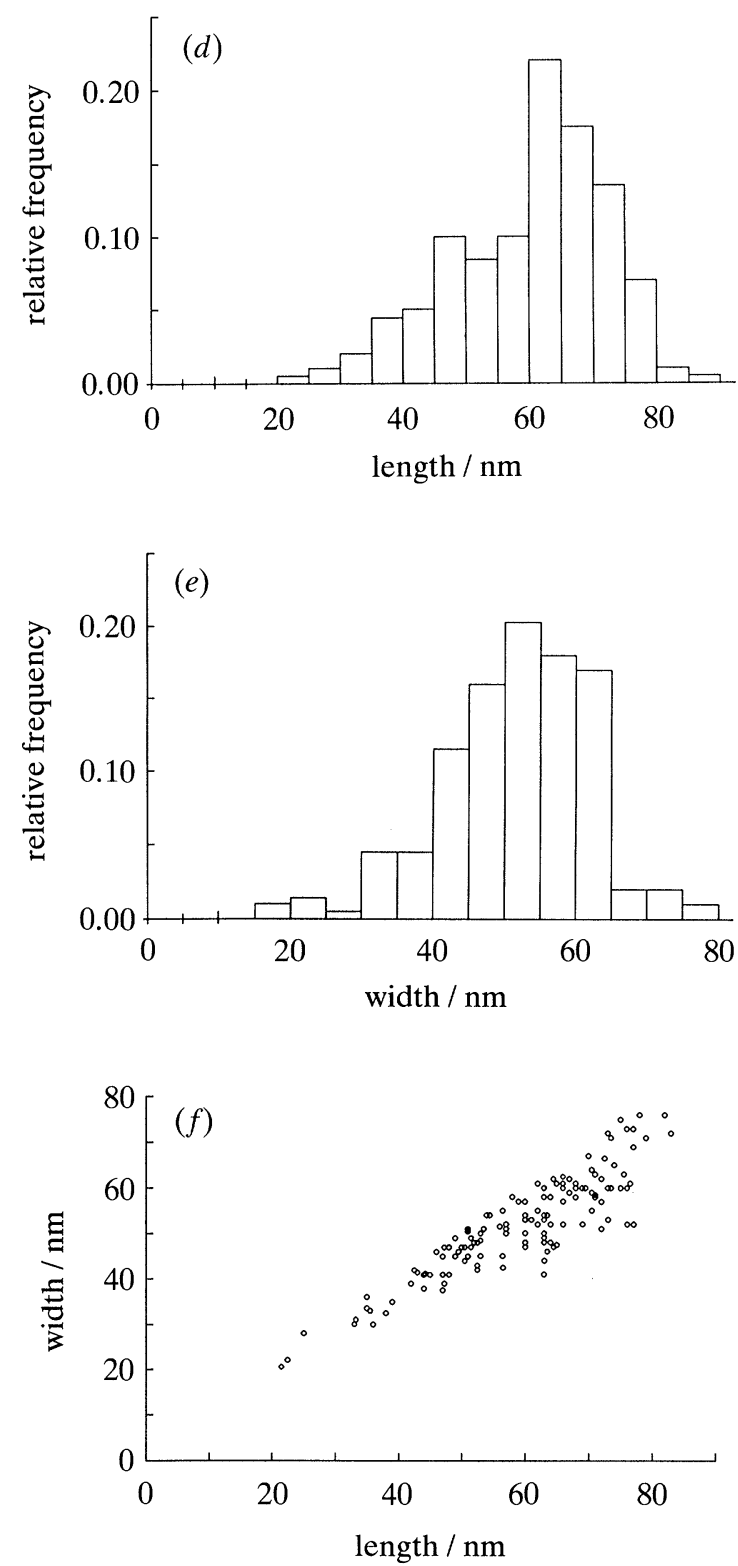

Figure 2. $(a-c)$ Crystal size data for strain MV-2: $(a)$ histogram of crystal length, $(b)$ histogram of crystal width, and $(c)$ length against width (aspect ratio). $(d-f)$ Crystal size data for strain MV-4: $(d)$ histograms of crystal length, $(e)$ histogram of crystal width, and $(f)$ length against width (aspect ratio). 


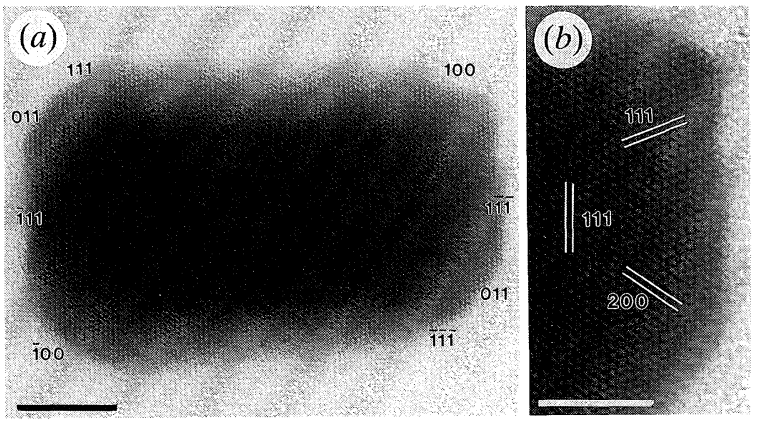

Figure 3. (a) Representative high-resolution lattice image of a magnetosome produced by strain MV-2. The crystal is viewed along the $\langle 110\rangle$ direction and crystal faces are identified. Scale bar $=10 \mathrm{~nm}$. (b) Enlargement of an area on (a) showing two sets of $\{111\}$ fringes and one set of $\{200\}$ fringes. Scale bar $=5 \mathrm{~nm}$. fringes in combination with others viewed in the $\langle 211\rangle$ orientation suggested that the crystal morphology was based on a hexagonal prism of $\{110\}$ faces, elongated along a $\langle 111\rangle$ axis and capped by $\{111\}$ faces (figure $4 a$ ). This morphology is similar to that determined for magnetosomes produced by the vibrioid bacterium MV-1 (Sparks et al. 1990) with the exception that the crystals from MV-2 cells show a variable combination of $\{111\},\{110\}$ and $\{100\}$ minor truncations in place of the well-defined $\{111\}$ faces of MV1 magnetosomes. This may result from differences in the growth conditions of strains MV-1 and MV-2.

High-resolution images of immature crystals showed rounded particles with aspect ratios similar to the mean value (1.84) determined for mature crystals. Whereas the side faces lying parallel to the morphological long axis were well defined, the end and (a)

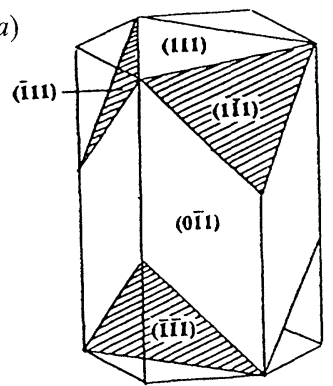

(b)

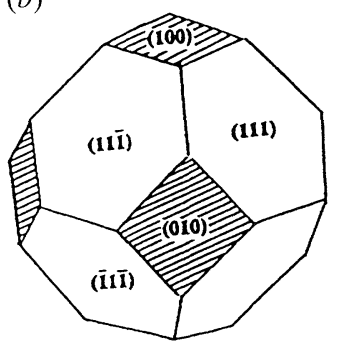

(c)

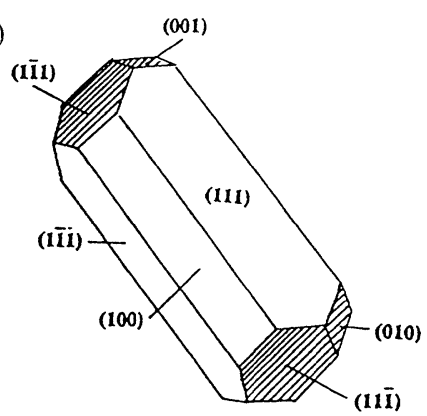

Figure 4. Idealized morphologies of magnetite crystals produced by (a) vibrioid cells, (b) Aquaspirillum magnetotacticum, and $(c)$ an uncultured ovoid-shaped bacterium. (Adapted from Mann \& Frankel (1989)).

(a)

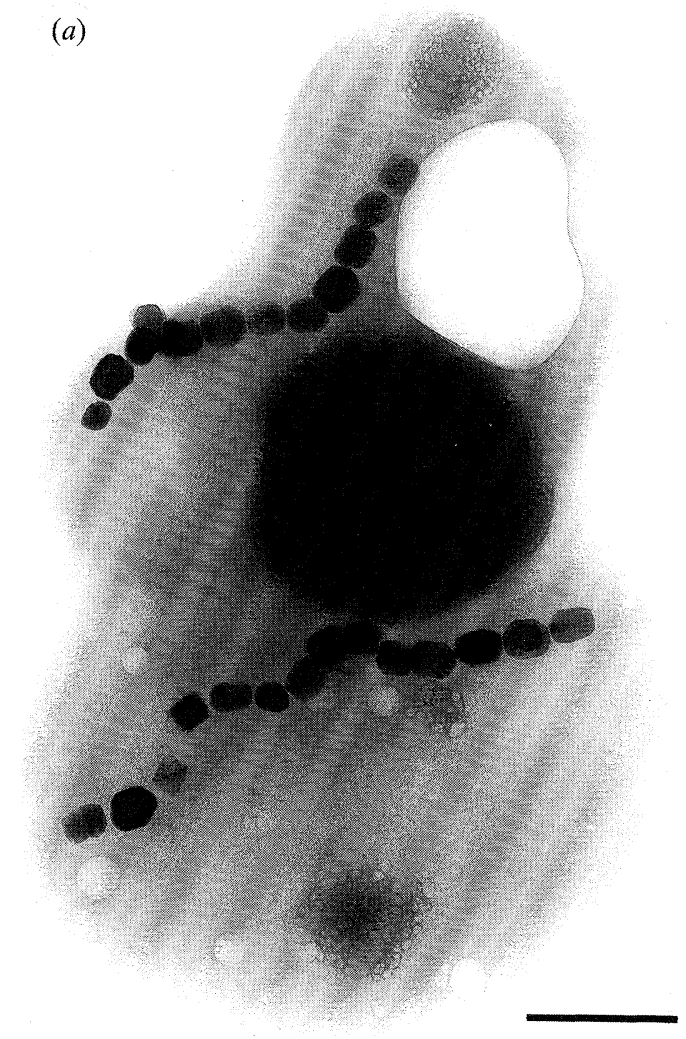

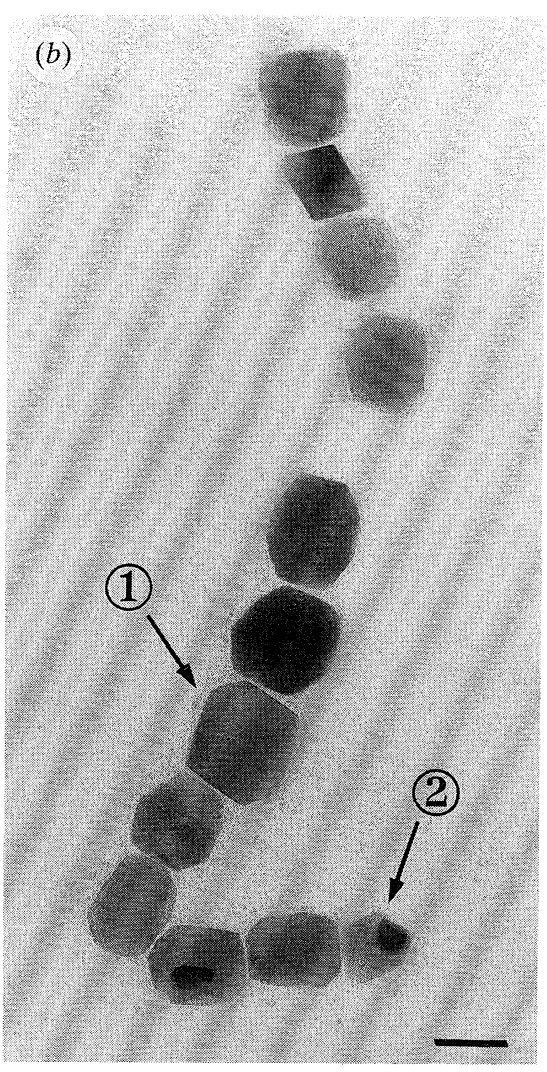

Figure 5. (a) Unstained cells of strain MV-4. Scale bar $=200 \mathrm{~nm}$. (b) Higher-magnification image of an individual chain of magnetosomes produced by strain MV-4. An electron-dense organic material is associated with the crystals (arrow 1). A twinned crystal is shown (arrow 2). Scale bar $=50 \mathrm{~nm}$. 


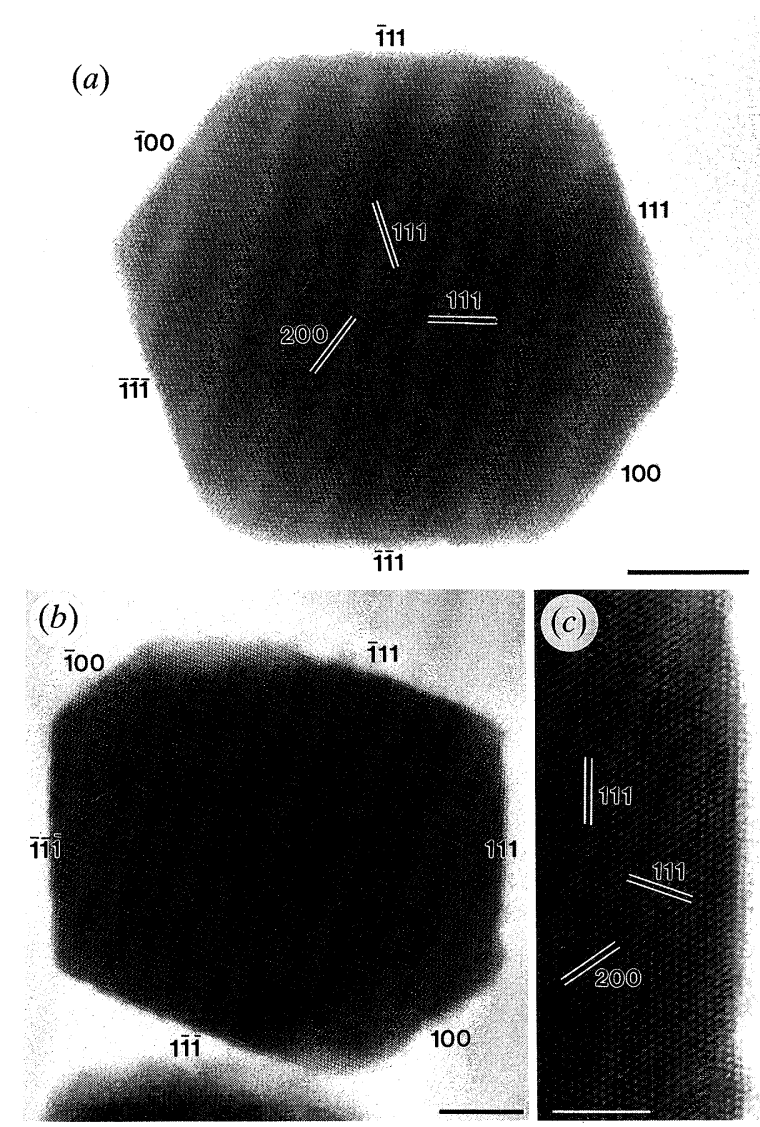

Figure 6. (a) High-resolution lattice images of magnetosomes produced by strain MV-4. The crystals are viewed in the $\langle 110\rangle$ zone. (a) Cubo-octahedral crystal showing welldefined lattice fringes and crystal faces. Scale bar $=10 \mathrm{~nm}$. (b) Partly enlongated cubo-octahedral crystal with welldefined faces. Scale bar $=10 \mathrm{~nm}$. (c) Enlargement of an area on $(b)$ showing atomic steps on a $\{111\}$ surface. Scale bar $=5 \mathrm{~nm}$.

truncated faces were not expressed, suggesting that these faces are stabilized at relatively late stages of crystal growth.

\section{(b) Strain $M V-4$}

Low-magnification images of strain MV-4 showed curved 'butter-bean'-shaped cells that contained a single chain of intracellular magnetite crystals aligned along the long axis of the bacterium (figure $5 a$ ). A significant number of bacteria contained chains of crystals that were disrupted from linearity, possibly because of artefacts associated with sample preparation. However, the effect was more pronounced than for MV-2 cells and suggests that the location of the magnetosome chain in strain MV-4 may not be as rigidly defined within the bacterium as in strain MV-2.

A detailed analysis of the MV-4 magnetosomes showed that the size and shape of the crystals were significantly different from those produced by strain MV-2 (tables 1 and 2, figure 2). In general, the crystals were slightly longer and considerably wider than those formed by MV-2 cells, with an aspect ratio (1.2) comparable with that determined for magnetite crystals synthesized by the coccoid bacterial strain,
MG-1 (Meldrum et al. 1993). Many crystals possessed either a cubo-octahedral morphology (figure $4 b$ ) characteristic of Aquaspirillum ('Magnetospirillum' (Schleifer et al. 1991)) magnetotacticum (Mann et al. $1984 a$ ), or a partly elongated cubo-octahedral form, similar to the highly elongated 'bullet-shaped' crystals of an uncultured ovoid-shaped magnetotactic bacterium (figure 4c) (Mann et al. $1987 a, b$ ). A significant number of MV-4 magnetosomes exhibited irregular morphologies, and were frequently twinned. Twin planes were usually perpendicular to the axis of elongation of the crystals, although a few crystals with a twin plane parallel to the long axis were also observed.

High-resolution electron micrographs confirmed the well-defined single crystal nature of the magnetosomes produced by strain MV-4 (figure 6). Crystals were principally imaged lying in the $\langle 110\rangle$ zone, although a small number were also observed along the $\langle 211\rangle$ and $\langle 111\rangle$ directions. Those viewed along the $\langle 110\rangle$ axis showed mutiple sets of lattice fringes (figure 6) which confirmed a cubo-octahedral morphology consisting of $\{111\}$ and $\{100\}$ faces. The $\{111\}$ faces were particularly well defined, and one set of these faces was often aligned perpendicular to the direction of the magnetosome chain. Although most crystals were partly elongated along the $\langle 211\rangle$ direction, several also showed an isotropic cubo-octahedral projection (figure 6).

\section{DISGUSSION}

The distinct contrast in crystal size and morphology exhibited by magnetosomes formed within the vibrioid bacterial strains MV-2 and MV-4 suggests that there may be different processes of magnetite biomineralization in these organisms. The magnetite crystals of strain MV-2 are virtually identical in morphology to those produced by a previously studied strain, MV-1 (Sparks et al. 1990). The mean crystal dimensions are very similar for both bacteria, although the dimensional range is considerably greater for MV-1. The number of crystals is greater and the crystal anisotropy more evident in the MV-2 strain, although both bacterial strains display aspect ratios which are greater than those reported for coccoid bacteria (Mann et al. 1984b; Meldrum et al. 1993). The differences between strains MV-1 and MV-2 may result from differences in the developmental status of the two cultures. Alternatively, the use of a sulphide-oxygen gradient medium for MV-2 cells, rather than the anaerobic heterotrophic growth medium used in previous studies of strain MV1 (Sparks et al. 1990), may be responsible for the increased number of magnetosomes observed in MV-2 cultures.

In contrast, the magnetosomes produced by strain MV-4 possess a cubo-octahedral morphology which, in its undistorted form, is similar to the crystal morphology produced by $A$. magnetotacticum cells (Mann et al. 1984a). The elongated variant of this basic form is similar to the bullet-shaped crystals produced by an unidentified, uncultured ovoid-shaped bacterium (Mann et al. $1987 a, b$ ). In both cases, the crystals are 
elongated along a $\langle 211\rangle$ axis but the MV-4 crystals are considerably less extended and maintain their centre of symmetry. The bullet-shaped crystals, by comparison, deviate considerably from their idealized morphology and frequently display a kink or curvature in their growth morphology. They also exhibit very different dimensions to the crystals of strain MV-4, having mean lengths and widths of $97.8 \mathrm{~nm}$ and $36.9 \mathrm{~nm}$, respectively, and aspect ratios in the range 3.33-4.0 (Mann et al. 1987 a). Thus, although the pattern of truncations present on the magnetosomes in strain MV-4 is very similar to that of the crystals in the uncultured ovoid-shaped cells, the bulk morphology of the crystals produced by the former is significantly different.

In summary, it has been demonstrated that the size and morphology of magnetite crystals produced by two cultured strains of vibrioid magnetotactic bacteria are significantly different. Although the biomineralization of magnetite is highly controlled in both strains, the distinct differences in crystal chemistry suggest that there may be a variety of mechanisms involved in the regulation of these functionally important bioinorganic products. It is noteworthy that cells of the vibrioid strain, MV-2, and those of the coccoid strain, MC-1 (Meldrum et al. 1993) produce magnetosome particles of magnetite, rather than an iron sulphide such as greigite $\left(\mathrm{Fe}_{3} \mathrm{~S}_{4}\right)$, in the presence of hydrogen sulphide. Iron sulphides including greigite (Heywood et al. 1990) and pyrite $\left(\mathrm{FeS}_{2}\right)$ (Mann et al. 1990) are found in the magnetosomes of some other magnetotactic bacteria which grow in the presence of hydrogen sulphide. Thus, the composition of the mineral phase of the magnetosomes appears to be controlled by the organism. The factors involved in the species- or strainspecific control of the composition, morphology and particle size of the mineral phase of the bacterial magnetosomes remain to be elucidated, and will be addressed in future work.

D.A.B. and R.B.F. are supported by the U.S. Office Of Naval Research grant ONR N00014-91-J-1290, and D.A.B. also by U.S. National Science Foundation grant MCB9117694. S. M. thanks the SERG for support of a postgraduate studentship (F.C.M.) and BP Research for postdoctoral support (B.R.H.).

\section{REFERENGES}

Bazylinski, D. A., Frankel, R. B. \& Jannasch, H. W. 1988 Anaerobic magnetite production by a marine magnetotactic bacterium. Nature, Lond. 334, 518-519.

Blakemore, R. P. 1975 Magnetotactic bacteria. Science, Wash. 190, 377-379.

Blakemore, R. P., Maratea, D. \& Wolfe, R. S. 1980 Isolation and pure culture of a freshwater magnetic spirillum in chemically defined medium. J. Bact. 140, 720-729.

DeLong, E. F., Frankel, R. B. \& Bazylinski, D. A. 1993 Multiple evolutionary origins of magnetotaxis in bacteria. Science, Wash. 259, 803-806.
Gorby, Y. A., Beveridge, T. J. \& Blakemore, R. P. 1988 Characterization of the bacterial magnetosome membrane. J. Bact. 170, 834-841.

Heywood, B. R., Bazylinski, D. A., Garrett-Reed, A., Mann, S. \& Frankel, R. B. 1990 Controlled biosynthesis of greigite $\left(\mathrm{Fe}_{3} \mathrm{~S}_{4}\right)$ in magnetotactic bacteria. Naturwissenschaften 77, 536-538.

Mann, S. \& Frankel, R. B. 1989 Magnetite biomineralization in unicellular microorganisms. In Biomineralization: chemical and biochemical perspectives (ed. S. Mann, J. Webb \& R. J. P. Williams), pp. 389-426. Weinheim: VCH Verlagsgesellschaft.

Mann, S., Frankel, R. B. \& Blakemore, R. P. $1984 a$ Structure, morphology and crystal growth of bacterial magnetite. Nature, Lond. 310, 405-407.

Mann, S., Moench, T. T. \& Williams, R. J. P. $1984 b$ A high resolution electron microscopic investigation of bacterial magnetite: implications for crystal growth. Proc. R. Soc. Lond. B 221, 385-393.

Mann, S., Sparks, N. H. G. \& Blakemore, R. P. $1987 a$ Ultrastructure and characterization of anisotropic magnetite crystals in magnetotactic bacteria. Proc. R. Soc. Lond. B 231, 469-476.

Mann, S., Sparks, N. H. C. \& Blakemore, R. P. $1987 b$ Structure, morphology and crystal growth of anisotropic magnetite crystals in magnetotactic bacteria. Proc. R. Soc. Lond. B 231, 477-487.

Mann, S., Sparks, N. H. G., Couling, S. B., Larcombe, M. G. \& Frankel, R. B. 1989 Crystallochemical characterization of magnetic spinels prepared from aqueous solution. J. chem. Soc. Faraday Trans. I 85(9), 3033-3044.

Mann, S., Sparks, N. H. C., Frankel, R. B., Bazylinski, D. A. \& Jannasch, H. W. 1990 Biomineralization of ferrimagnetic greigite $\left(\mathrm{Fe}_{3} \mathrm{~S}_{4}\right)$ and iron pyrite $\left(\mathrm{FeS}_{2}\right)$ in a magnetotactic bacterium. Nature, Lond. 343, 258-261.

Mann, S., Sparks, N. H. G. \& Board, R. G. 1991 Magnetotactic bacteria: microbiology, biomineralization, palaeomagnetism and biotechnology. Adv. microb. Physiol. 31, $125-181$.

Matsuda, T., Endo, J., Osakabe, N. \& Tonomura, A. 1983 Morphology and structure of biogenic magnetite particles. Nature, Lond. 302, 411-412.

Matsunaga, T., Sakaguchi, T. \& Tadokoro, F. 1991 Magnetite formation by a magnetic bacterium capable of growing aerobically. Appl. Microbiol. Biotechnol. 35, 651655.

Meldrum, F. C., Mann, S., Heywood, B. R., Frankel, R. B. \& Bazylinski, D. A. 1993 Electron microscopy study of magnetosomes in a cultured coccoid magnetotactic bacterium. Proc. R. Soc. Lond. B 251, 231-236. (Preceeding paper.)

Moench, T. T. 1988 Bilophococcus magnetotacticus gen.nov.sp.nov., a motile magnetic coccus. Antonie van Leeuwehoek 54, 483-496.

Schleifer, K. H., Schuler, D., Spring, S., Weizenegger, M., Amann, R., Ludwig, W. \& Kohler, M. 1991 The genus Magnetospirillum gen.nov. Description of Magnetospirillum gryphiswaldense sp.nov. and transfer of Aquaspirillum magnetotacticum to Magnetospirillum magnetotacticum comb.nov. Syst. appl. Microbiol. 14, 379-385.

Sparks, N. H. C., Mann, S., Bazylinski, D. A., Lovely, D. R., Jannasch, H. W. \& Frankel, R. B. 1990 Structure and morphology of magnetite formed by a marine magnetotactic bacterium and dissimilatory iron-reducing bacteria. Earth planet. Sci. Lett. 98, 14-22. 